Смоляк Олег Степанович доктор мистеитвознавства, Тернопільський національний педагогічний університет ім. Володимира Гнатюка, Тернопіль, Україна smolyak.te@gmail.com

\title{
ТРАДИЦЙНА СКЛАДОВА СИМВОЛІЗМУ ЛЕСЯ КУРБАСА (НА МАТЕРІАЛІ ГАЇВОК 3 СЕЛА СТАРИЙ СКАЛАТ ПІДВОЛОЧИСЬКОГО РАЙОНУ ТЕРНОПІЛЬСЬКОЇ ОБЛАСТІ)
}

Мета роботи. Стаття пов'язана з характеристикою традиційних елементів символізму видатного актора та режисера, реформатора українського театру Леся Курбаса, окресленням традиційних підходів в процесі його сценічних театральних відтворень, як основи українського новаторського театру. Методологія дослідження полягає в поєднанні аналітико-синтетичного методу 3 історико-типологічним методом, що дає змогу дослідити символіку гаївок рідного села Леся Курбаса, яка безпосередньо чи опосередковано відобразилася на творчому мисленні режисера в його постановках вистав, а за допомогою методу семіотичного аналізу довести, що в основі рухової пластики лежить цілковите поєднання умовної жестикуляції з натуралістичними ініціальними жестами. Наукова новизна роботи полягає в тому, що запропонована автором стаття вперше осмислює зв'язок українських гаївок з символікою в творчості Леся Курбаса, доводить те, що традиційні народні етнокультурні чинники живили творчий талант Леся Курбаса, збагачували його етнокультурне розуміння та допомагали створювати неперевершені сценічні образи. Висновки. Доведено, що хореографічні рухи в старо-скалатських гаївках побудовані на фігурах, які переважно базуються на символіці дохристиянських вірувань. Найвиразовішими руховими елементами є манера ходьби колом, змійкою, двома шеренгами, різноманітна жестикуляція. Символіка рухів у гаївках, які здавна побутували в рідному селі Леся Курбаса, стала складовою формування новаторських засад його театру. Синкретичний образ, метафоричність сценічної дії, згусток-символ окремих персонажів стали важливими чинниками в театральних постановках Леся Курбаса.

Ключові слова: Лесь Курбас, символізм, рухова пластика, гаївка, обряд.

Смоляк Олег Степанович, доктор искусствоведения, Тернопольский национальный педагогический университет им. Владимира Гнатюка, Тернополь, Украина

Традиционная составляющая символизма Леся Курбаса (на материале гаивок из села Старый Скалат Подволочинского района Тернопольской области) 
Цель работы. Статья связана с характеристикой традиционных элементов символизма выдающегося актера и режиссера, реформатора украинского театра Леся Курбаса, описанием традиционных подходов в процессе его сценических театральных воспроизведений, как основы украинского новаторского театра. Методология исследования заключается в сочетании аналитико-синтетического метода с историко-типологическим методом, что позволяет исследовать символику гаивок родного села Леся Курбаса, которая непосредственно или косвенно отразилась на творческом мышлении режиссера в его постановках спектаклей, а с помощью метода семиотического анализа доказать, что в основе двигательной пластики лежит полное сочетание условной жестикуляции с натуралистическими инициальными жестами. Научная новизна работы заключается в том, что предложенная автором статья впервые осмысливает связь украинских гаивок с символикой в творчестве Леся Курбаса, доказывает то, что традиционные народные этнокультурные факторы питали творческий талант Леся Курбаса, обогащали его этнокультурное понимание и помогали создавать непревзойденные сценические образы. Выводы. Доказано, что хореографические движения в старо-скалатских гаивках построены на фигурах, которые в основном базируются на символике дохристианских верований. Самыми выразительными двигательными элементами являются манера ходьбы кругом, змейкой, двумя шеренгами, разнообразная жестикуляция. Символика движений в гаивках, которые издавна существовали в родном селе Леся Курбаса, стала составляющей формирования новаторских принципов его театра. Синкретический образ, метафоричность сценического действия, сгустоксимвол отдельных персонажей стали важными факторами в театральных постановках Леся Курбаса.

Ключевые слова: Лесь Курбас, символизм, двигательная пластика, гаивка, обряд.

Smoliak Oleh, Doctor of Art Criticism, Ternopil Volodymyr Hnatyuk National Pedagogical University, Ternopil, Ukraine

Traditional component of Les Kurbas's symbolism (based on haivkas of the village of Staryi Skalat, Podvolochyn district, Ternopil region)

The purpose of the article. The article deals with the characterization of traditional elements of symbolism of the outstanding actor and director, reformer of Ukrainian theater, Les Kurbas, and aims to outline traditional approaches in the process of staging his theatrical plays as the basis of Ukrainian innovative theater. The research methodology consisted in the combination of the analytical-synthetic and historical-typological methods, which allowed for investigating the symbols of haivkas (ritual songs) of Les Kurbas's native village, which directly or indirectly influenced the creative thinking of the director in his on-stage productions, and, using the method of semiotic analysis, made it possible to prove that the basis of motion plastic is the complete combination of conditional gestures and naturalistic initial gestures. The scientific novelty of the work lies in the first attempt to 
comprehend the connection between Ukrainian haivkas and the symbols in Les Kurbas's creative work in order to prove that traditional folk ethnocultural factors nourished Les Kurbas's creative talent, enriched his ethnocultural understanding and helped to create unsurpassed scenic images. Conclusions. It was proved that choreographic movements in haivkas of Staryi Skalat are made of figures predominantly based on the symbols of pre-Christian beliefs. The most visible motion elements are the styles of walking in a circle, a snake, two rows, and a variety of gestures. Symbols of movements in haivkas, which have long been used in Les Kurbas's native village, became an integral part of the formation of the innovative principles of his theater. Syncretic image, metaphorical stage action, cluster-symbol of individual characters became important factors in Les Kurbas's theatrical productions.

Key words: Les Kurbas, symbolism, motion plastic, haivka, rite.

Вступ. У період відродження української національної культури найбільший інтерес у науковців викликають ті питання, які пов'язані 3 переосмисленням творчих біографій видатних митців. До останніх, насамперед належать імена, які були проскрибовані комуністичним режимом через відхилення від методу соціалістичного реалізму. До таких імен належить і видатний український актор, режисер, педагог, культурно-громадський діяч, творець нового українського театру Лесь Курбас.

Питаннями осмислення творчих здобутків визначного Майстра сцени займалися українські вчені-мистецтвознавці Лесь Танюк [15], Н. Корнієнко [8], Ю. Бобошко [2], Г. Веселовська [4], І. Волицька [5П. Медведик [10], О. Василишин [3] та ін., але на етнокультурні аспекти його творчого становлення мало хто звертав увагу, а якщо й звертав, то дуже побіжно та поверхово.

Мета дослідження - висвітлити ті традиційні народні етнокультурні чинники, зокрема символіку гаївок, які живили творчий талант Леся Курбаса, збагачували його етнокультурне розуміння, заземлене в традиційну театральну культуру рідного народу і без яких його сценічні образи та постановки ніколи не отримали б таких значних мистецьких висот.

Виклад основного матеріалу. Неабияку роль у становленні творчої особистості відіграє традиційна народна культура. Особливо вона показова в тих випадках, коли формується культурно-мистецький діяч, зокрема актор чи режисер. Адже, він постійно знаходиться в полоні традиційних обрядових дійств, які багаті театральними елементами. Вони, зазвичай, залишають опосередкований слід в процесі становлення митця, зокрема того, творчість якого $\epsilon$ неповторною. Позасумнівом $\epsilon$ те, що й видатний актор та реформатор театру Лесь Курбас не оминув впливу місцевих обрядових дійств, які захоплювали його в дитинстві і, які своєю символікою та образною системою, вплинули на стилістичне становлення митця.

У селі Старий Скалат Підволочиського району Тернопільської області, де народився Великий Лесь Курбас, до 60-х рр. ХХ ст. активно побутували весняні пісні (місцеві жителі називають їх гаӥвками). Вони власне належать до тих 
обрядових пісень, в яких найкраще збереглися символічні елементи, зокрема в їхніх рухових елементах.

Як показав аналіз, у гаївках, що побутували в цій місцевості збереглися три типи рухових елементів - кругові, ключові та дворяднікругові, ключові та дворядні ${ }^{1}$.

Серед записаного в селі Старий Скалат гаївкового матеріалу найчастіше зустрічаються кругові рухи. Треба зауважити, що круговий рух у гаївках може бути рухомим та нерухомим. Якщо серед записів другої пол. XIX - поч. XX ст. у гаївках переважало нерухоме коло (у збірнику «Гаївки» В. Гнатюка [9] із 39ти кругових гаївок - 29 відтворені нерухомим колом), то серед староскалатських записів переважає рухоме коло (із 25-ти усіх записів у 16 - рухоме коло). Основною підставою для такої переміни стала втрата анімістичного світогляду, що був визначальним чинником у регулюванні рухових елементів, а в кінцевому результаті - сприйняття гаївкових обрядів як суто ігрових дійств. За семантикою рухів кругові гаївки творять три різновиди: 1) коло без головних персонажів; 2) коло з головними персонажами в ньому; 3) коло з головними персонажами в ньому та поза ним. Найпоширенішим різновидом у староскалатських гаївках $\epsilon$ рух колом без головних персонажів. Це найбільш уніфікований руховий спосіб відтворення весняних пісень, який в давнину зустрічався рідко (в збірнику «Гаївки» В. Гнатюка рух колом без головних персонажів притаманний лише 4-м гаївкам). Треба зауважити, що цей руховий елемент зустрічається в більшості гаївок пізнішого походження. Серед аналізованого матеріалу рух колом без головних дійових осіб зафіксований в таких гаївках як «Ой ленку мій, ленку», «Чом вулиця не зеленая», «Ой плавали рибки, плавали», «Ходить коничок понад річкою», «Та котися горошку в три стручки», «Десь тут була Подоляночка», «Зайчику», «Коструб», «Вию вінець», «Ой в’яжіться огірочки», «Воротар» (усіх - 14 зразків).

«Найголовніша фігура-образ у водінні веснянок-гаївок, - як зазначає С. Килимник, - це коло (в Галичині називають «колесо»). Це коло знаменує сонце, хвалу йому, благання-чаклування його. Воно символізує благання тепла, прискорення весни, високого урожаю тощо» [7, с. 184]. Треба зауважити, що рух колом у гаївках, зазвичай, йде за сонцем, тобто в такому напрямку, як сонце рухається по небу - зі сходу на захід.

Найпоказовішою в підгрупі кругових гаївок без головних персонажів $\epsilon$ гаївка «Чом вулиця не широкая», що символічно відтворює розквіт весняної природи, зокрема трави (в давнину наші предки водили весняні пісні на лугах, в гаях). Треба зазначити, що в давні часи трави входили в розряд тотемівсимволів, яким наші предки поклонялися: на лугах чи в гаях проходив вибір пари, формувалися подружні стосунки. Звертаючи увагу на рухові елементи цієї гаївки, насамперед, спостерігається іiі динамічність, що реалізується завдяки постійному підніманню та опусканню рук, подібно до колихання трави,

\footnotetext{
${ }^{1}$ Уперше в українській музичній фольклористиці типологія рухових елементів у весняних піснях розроблена нами в статті «Танкові малюнки у гаївках Західного Поділля» [14].
} 
а також поступове пришвидшення ㄲï темпу. Про гаївку «Чом вулиця не широкая» М. Грушевеький писав, що «в цьому мотивові ми можемо відчути багатство пробудженого космічного руху, прихід зеленої весни» [6, с. 201-202].

Друга підгрупа кругових гаївок із головними персонажами в ньому властива як давнішим варіантам, так і пізнішим. У давніших друкованих джерелах (маємо на увазі в збірнику «Гаївки» В. Гнатюка) їхня кількість сягає біля 50\%, а в старо-скалатському репертуарі - лише у 2-х зразках «Подоляночка» та «Зайчик». До речі, ці гаївки відтворені рухомими колами із одним персонажем у ньому. Найчастіше зустрічається нерухоме коло із одним персонажем у ньому. Треба зазначити, що в даному руховому підтипі найактивнішу функцію відіграє головний персонаж (Подоляночка, Зайчик), який знаходиться в епіцентрі кола. Він перебуває переважно в стоячій (рідше у сидячій) позі й всім своїм тілом імітує співаний текст. Деколи головний персонаж ходить невеличким колом у зворотному напрямі до руху учасників, тримаючи в руках якийсь предмет: вербовий прутик, вишивану хустку (в залежності від мотивації змісту пісні) і б'є ним наступного, вибраного персонажа. Адже биття вербовим прутом один одного, як зазначає український вчений-етнолог Є. Онацький, - «звичай ще дохристиянський: він має на меті передати тому, кого б'ють, творчої розбудженої енергії та здоров'я» [11, с. 139].

Багато символічних рухів збережено до нашого часу в стародавній гаївці «Ой ти, Данчику, Білоданчику», яка репрезентує даний орнаментальний тип. Ця гаївка відмінна від багатьох аналогічних інших тим, що в ній замість головного персонажа-дівчини в колі перебуває парубок-«білоданчик». В образі сірогобілого Білоданчика С. Килимник вбачає «весняний вітер, що розганяє ранні білі тумани над дунайчиком-водою» [7, с. 221]. На нашу думку, насамперед, збереглися елементи андрогіну. Власне тут яскраво виражене шлюбування чоловічого й жіночого начал, яке у весняний період ставало образносимволічним знаком у народних світоглядних уявленнях.

В українському весняному обрядовому фольклорі лише в незначній кількості гаївок представлене нерухоме коло 3 одним учасником у колі та з одним за межами його. Ця символічна фігура властива старо-скалатській гаївці «Кіт і миша». Треба зауважити, що в цьому орнаментальному малюнку розширюється композиційна сфера дії завдяки введенню нового, більш динамізованого персонажа, який знаходиться поза межами кола. На відміну від останнього, персонаж, що знаходиться в середині кола, пантомімічний. Персонаж-чоловік, що знаходиться поза колом, намагається час від часу вдарити вербовим прутом персонажа-дівчину, що стоїть в центрі кола. Як бачимо, акт вдаряння вербовим прутом у весняній обрядовості - поширене явище. Тут збереглися елементи ритуальної боротьби двох начал - чоловічого й жіночого - на зламі зими і весни, що означає «актуалізацію космогонії, перехід від Хаосу до Космосу» [9, с. 69]. До речі, кількість учасників, що перебувають в колі та поза межами його, може бути різна: від одного до п’яти учасників. 
У старо-скалатській гаївковій традиції збереглася стародавня гра-містерія «Коструб», в якій значно краще збереглася динамізація рухового орнамента, ніж у попередній. У цій гаївці гармонійно поєднано декілька образів-символів: боротьба двох антагоністичних пір року (зими і весни), символ весняного сонця, символ чоловіка-нелюба, символ народження і смерті. Через те в цьому дійстві використовується полісемантика рухів, мотивів, співу-речитативу, пантоміми тощо. Вони імітують рух кола-сонця на схід і на захід, кроки жваві і кроки повільні, затоптування та підскакування, припліскування в долоні і вибирання пари.

До сьогодні в старо-скалатській гаївковій традиції зберігається грамістерія «Подоляночка». Її знають всі: і дорослі, і діти. Останнім часом вона перейшла «кордони» весняної обрядовості i стала набутком дитячого репертуару, виконуваного протягом всього весняно-літнього періоду. У давні часи це була суто дівоча гра. Ї̈ї рухові елементи наступні: коло дівчат рухається за сонцем, а в середині його сидить дівчина-подоляночка і рухами, жестами та мімікою відтворює співаний текст. У досліджуваній місцевості побутують два танкових варіанти «Подоляночки». Перший - це повністю рухоме коло від початку до кінця співу, а другий - напіврухоме (у п'ятирядковій строфі під час співу двох перших строф учасники гри рухаються, а під час трьох наступних зупиняються й імітують разом з Подоляночкою словесний текст).

Треба зазначити, що в грі «Подоляночка» закладена багатозначна символіка. Зокрема, коло дівчат символізує рух сонця, дівчина в середині весну-землю, що спочатку спить, укутана морозами, а потім поступово воскресає. «Саме "Подоляночкою" і подібними до неї іграми молодь в сиву давнину в молитовному настрої викликала та чарувала весну, воскресіння матері-природи, а з нею і гаряче сонце, і багату родючість землі, і одруження» [7, c. 218].

У старо-скалатських гаївках також збереглися рухи, які реалізуються колом-черепашкою та колом-спіралькою. Коло-черепашка притаманне гаївці «Вию вінець». Їй властиві наступні рухові дії: дівчата беруться за руки, йдуть «ключем» i співають, а перша - ведуча одразу завертає i творить «черепашковий» завиток, який щоразу зменшується до тих пір, поки «ключ» не стане колом-черепашкою. Цей орнаментальний малюнок, що імітує виття весільного віночка, символізує щасливе одруження (коли учасники гри йдуть за сонцем) і відвертає одруження з нелюбом (коли вони виходять попід руки 3 середини кола-черепашки).

Рух колом-спіраллю втілений в старо-скалатській гаївці «Огірочки». За первісними світоглядними уявленнями такого роду гаївки впливали на ріст зерна, на розвиток рослин, а в кінцевому результаті - на високий урожай. Рухові елементи в цій гаївці втілюються наступним чином: дівчата беруться за руки і стають в ряд, а ведуча починає йти і веде всіх попід руки останньої пари, потім робить коло-спіраль і йде попід руки передостанньої пари і таким чином до самого кінця ряду. Коли вже всі «завилися» і зробили коло-спіраль, тоді починають «розвиватися» в протилежний бік. Отже, «звиваючись на взір 
горохового стебла чи огіркового огудиння, учасники хороводу несвідомо вже для себе мають очевидно пособляти доброму росту гороху чи іншої городини» [6, с. 101].

У старо-скалатській гаївковій традиції зустрічаються і ключові рухи. Вони переважно представлені в гаївках давнішої фольклорної верстви. Ключовий рух властивий гаївці «Ми кривого танцю йдемо». У давній період цим танцем розпочинався навесні обрядовий обхід священних гаїв і закінчувався весь весняний обрядовий цикл свят.

Цей танець акумулює в собі багатозначні елементи філософського змісту. Три хлопчики, що стоять трикутником, або аналогічно запнуті в землю три вербових прутики символізують небо, повітря і землю або народження, життя і смерть. У рухах цієї гаївки акумулюються наступні символічні знаки: рух сонця небом, зміна пір року, зміна дня і ночі, життя і смерть. Особливо це відчутно в пісенному приспіві-формулі «то вгору, то в долину, то в рожу, то в калину», яка символізувала піднімання та опускання сонця, хід людського життя, адже рожа - це символ життя, а калина - символ смерті. 3 цього приводу Д. Білецький писав, що «кривий танець символізує розбуджування життєвої сили в природі» [1, с. 96].

В інших місцевостях Західного Поділля, існувала традиція водити гаївку «Ми кривого танцю йдемо» в формі вісімки (в народі іiі називають безконечником) та змійки. Орнамент цих рухів яскраво зафіксований в писанках. Як бачимо, у ключових рухах закладена символіка вічності розвитку природи, людського буття, розквіту енергії та сили.

У старо-скалатській гаївковій традиції до 60-х рр. ХХ ст. зберігалися гаївки, в яких відтворювалися дворядні рухові елементи.

Двошеренговий різновид представлений гаївкою «Жельман». Вона, як зазначає С. Килимник, «... є цілком синкретичним твором глибокої давнини і вірно відображає період родового побуту, тодішнього господарювання, взаємин сусідніх родів, первісні хлібні культури, парування (одруження)» [7, с. 208]. Ця гаївка характеризується постійною як руховою, так і драматургічною динамізацією. Вона, власне, символізує викуп дівчини одним родом в іншого. Цей різновид танків символізує, на нашу думку, рух весняних явищ природи - хмар, дощу, вітру, зріст злакових та городніх культур.

У першій пол. ХХ ст., як розповідають старо-скалатські старожили, побутувала двошеренгова гаївка «Воротар», якій властиве зіставлення двох «ключів»- малого і великого. Малий «ключ»- це двоє дівчат, що творять «ворота», а великий «ключ» - всі інші. Вони співають антифонним способом, а в кінці співу малий «ключ» піднімає руки - відчиняє «ворота», великий «ключ» біжить попід них. Останню дівчину 3 великого «ключа» затримують і вимагають викуп. Як бачимо, у воротарній гаївці хореографічний малюнок на перший погляд є більш загадковим у порівнянні із попередніми. Адже, він символізує «небесні ворота», через які, за віруваннями стародавніх українців, приходили на землю новонароджені душі і відходили ними душі померлих. 
Через ті «ворота» приходить на землю і паняночка-Весна, і всетворяще сонце, і тепло, і урожай, і щастя, і добро, і любов.

Третій різновид двошеренгових гаївок - це мостовий. У досліджуваній місцевості він представлений гаївкою «Мости» і характеризується спільним для нього хореографічним малюнком - символічним відтворенням хиткого місточка, по якому йде дівчина. Цей створений учасниками «живий місточок» $\epsilon$ рухомим. Стародавні українці вірили, що цим мостом приходить на землю Весна і іiі донька-Паняночка. 3 цього приводу О. Потебня зазначав, що «... зоря відчиняє небесні ворота та відкриває мости, а небо подає животворчу воду в образі дощу та роси, яка ототожнюється 3 медом» [12, с. 129]. Тут неважко відчути присутність води (адже, міст буває переважно через воду) як животворчого начала, що символізує очищення, здоров'я, підбір пари.

Наукова новизна роботи полягає в тому, що запропонована автором стаття вперше осмислює зв'язок українських гаївок з символікою в творчості Леся Курбаса, доводить те, що традиційні народні етнокультурні чинники, зокрема символіка гаївок, живили творчий талант Леся Курбаса, збагачували його етнокультурне розуміння та допомагали створювати неперевершені сценічні образи.

Висновки. Отже, хореографічні рухи в старо-скалатських гаївках побудовані на фігурах, які переважно базуються на символіці дохристиянських вірувань. В основі цієї рухової пластики лежить цілковите поєднання умовної жестикуляції 3 натуралістичними ініціальними жестами. Найвиразовішими руховими елементами є манера ходьби колом, змійкою, двома шеренгами, різноманітна жестикуляція - підіймання та опускання рук 3 різними атрибутами: квітками, хустками, прутиками, які значно підсилювали виразовість жестикуляції. Уся пластика виразових засобів була умовною, але багатозначною: один і той же рух чи жест передавав різні дії, душевні стани, що випливали із семантики слова та музики. Немає сумніву в тому, що символіка рухів у гаївках, які здавна побутували в рідному селі Леся Курбаса, стала складовою формування новаторських засад його театру. Адже, синкретичний образ, метафоричність сценічної дії, згусток-символ окремих персонажів стали важливими чинниками в театральних постановках Леся Курбаса. Їхня засадничість й вивела український театр на рівень світового.

\section{Список використаних джерел}

1. Білецький Л. Історія української літератури / Л. Білецький. - Авгсбург : [Накладом Укр. церков. вид-ва], 1947. Т. 1 : Народня поезія. - 1947. - 328 с.

2. Бобошко, Ю. М. Режисер Лесь Курбас / Ю. М. Бобошко. - Київ : Мистецтво, 1987. - 197 с.

3. Василишин О. Меморіальний музей-садиба Леся Курбаса: нариспутівник / О. Василишин. - Тернопіль : Укрпрінт-Захід, 2007. - 82 с.

4. Веселовська Г. І. Дванадцять вистав Леся Курбаса / Г. І. Веселовська. Київ : ДЦТМ ім. Леся Курбаса, 2004. - 317 с. 
5. Волицька I. Театральна юність Леся Курбаса: (Проблема формування творчої особистості) / І. Волицька. - Львів : НАН України, Ін-т народознавства, 1995. $-152 \mathrm{c}$.

6. Грушевський М. С. Історія української літератури. В 6 т. 9 кн. / М. С. Грушевський. - Київ: Либідь, 1993. - Т.1. - 389 с.

7. Килимник С. Український рік у народних звичаях в історичному освітленні / С. Килимник. - Київ : АТ Кобзар, 1993. - Т. 2: Весняний цикл. $392 \mathrm{c}$.

8. Корнієнко Н. Лесь Курбас: репетиція майбутнього / Н. Корнієнко. Київ : Либідь, 2007. - 328 с.

9. Гнатюк В. Матеріали до української етнології. Гаївки / В. Гнатюк.. Львів: НТШ, 1909. - Т.12. - 267 с.

10. Медведик П. Курбасові весняні вечори (До 100-річчя від дня народження О.С.Курбаса) / П. Медведик // Жовтень. - 1987. - № 4. - С. 80-88.

11. Онацький $Є$. Українська мала енциклопедія. У 8 т. 16 кн. Кн.2. / Є. Онацький. - Буенос-Айрес : Накладом Адміністратури УАПЦ в Аргентині, 1957 - 1967. Книга 2. - Буенос-Айрес, 1958. - 298 с.

12. Потебня А. А. Объяснение малорусских и сродных народных песен / А. Потебня. - Варшава: Тип. М.Земкевича и В.Носковского, 1883. -268 с.

13. Смоляк О. Весняна обрядовість Західного Поділля 3 контексті української культури : монографія. / О. С. Смоляк. - Тернопіль: Астон, 2001. Ч.2. $-392 \mathrm{c}$.

14. Смоляк О. Танкові малюнки у гаївках Західного Поділля / О. Смоляк // Музика та дія в традиційному фольклорі: зб. наук. пр. - Львів, 2001. - С. 56-68.

15. Танюк Лесь. Талан і талант Леся Курбаса / Л. Танюк. - М-во культури і туризму України, Держ. центр театр. мистец. ім. Л. Курбаса, Нац. опера України, Держ. п-во «Мистецтво України». - Київ : [б. в.], 2007. - 44 с.

\section{References}

1. Biletskyi, L. (1947). History of Ukrainian Literature. Augsburg: The Administration of the UAOC in Argentina, 1957-1967. Vol. 1: Folk Poetry.

2. Boboshko, Yu. (1987). Directed by Les Kurbas. Kyiv, Mystetstvo.

3. Vasylyshyn, O. (2007). Memorial Museum-estate of Les Kurbas: essayguide. Ternopil: Ukrprint-Zakhid.

4. Veselovska, H. (2004). Twelve performances by Les Kurbas. Kyiv: DTsTM im. Lesia Kurbasa.

5. Volytska, I. (1995). Theatrical youth of Les Kurbas: (The problem of forming a creative personality). Lviv: National Academy of Sciences of Ukraine, Institute of Ethnology.

6. Hrushevskyi, M. (1993). History of Ukrainian Literature. In 6 vol. 9 books. Vol. 1. Kyiv: Lybid.

7. Kylymnyk, S. (1994). Ukrainian year in folk customs in historical light. Vol. 2. Spring cycle. Kyiv: Oberegy.

8. Korniienko, N. (2007). Les Kurbas: rehearsing the future. Kyiv: Lybid. 
9. Hnatiuk, V. (1909). Materials for Ukrainian ethnology. Vol. 12. Lviv: Shevchenko Scientific Society.

10. Medvedyk, P. (1987). Kurbas Spring Evenings (To the 100th anniversary of O. S. Kurbas). Zhovten [October], no. 4, pp. 80-88.

11. Onatskyi, Ye. (1958). Ukrainian small encyclopedia. In vol. 8. 16 Books Books 2. Buenos Aires: The Administration of the UAOC in Argentina, 1957-1967

12. Potebnya, A. (1883). Explanation of Little-Russian and related folk songs. Warsaw: Printing house of M. Zemkevich and V. Noskovsky.

13. Smoliak, O. (2001). The Spring Ceremony of Western Podillya in the Context of Ukrainian Culture. Monograph. Part 2. Ternopil: Aston.

14. Smoliak, O. (2001). Dance drawings in the haivkas of Western Podillya. Muzyka ta diia $v$ tradytsiinomu folklori: Zbirnyk naukovykh prats $[$ Music and Performance in Traditional Folklore: Collection of Scientific Papers]. pp. 56-68.

15. Taniuk, L. (2007). Talan and talent of Les Kurbas. Ministry of Culture and Tourism of Ukraine, L. Kurbas State Center of Theatre Arts, National Opera of Ukraine, State Enterprise "Art of Ukraine”. Kyiv.

(С) Смоляк О. С., 2018

УДК 792.73:7.097

\author{
Совгира Тетяна Ігорівна \\ кандидат мистецтвознавства, \\ Київський національний університет \\ культури і мистецттв, \\ Київ, Україна \\ STIsovgyra@gmail.com
}

\title{
ВИКОРИСТАННЯ ТЕХНІЧНИХ МОЖЛИВОСТЕЙ ВІЗУАЛЬНОГО МИСТЕЦТВА В СЦЕНІЧНОМУ ПРОСТОРІ
}

Мета роботи. Стаття присвячена дослідженню питань методики використання технічних можливостей візуального мистецтва у процесі створення сценічних розважальних заходів. Відповідно до мети з'ясовуються поняття «візуальне мистецтво», «техніка» та «технологія», «інтерактивність» тощо, досліджується специфіка тривимірного відеомеппінгу, відеоінсталяцій як напрямків сучасного мистецтва. Методи дослідження: в роботі застосовано загальнонаукові та конкретнонаукові методи: аналітичний - при аналізі філософської, мистецтвознавчої, культурологічної літератури 3 теми дослідження; історичний - для з'ясування етапів становлення напрямків відеоарту як мистецького явища; теоретичний - для з'ясування загальної природи візуального мистецтва та його специфіки в сфері сценічних мистецтв; порівняльно-типологічний - для виявлення рис подібності і відмінності сценічного та візуального мистецтв як видів мистецтва; концептуальний - при 